\title{
REVIEW I Populäre Musikkulturen im Film. Inter- und transdiziplinäre Perspektiven / Popular Music Cultures in Film. Inter- and transdisciplinary Perspectives
}

Carsten Heinze and Laura Niebling Eds.

Wiesbaden: Springer VS, 2016

ISBN: 978-3-658-10895-3 (PB)

\section{Dr. Philipp Schmerheim}

\author{
Universität Bremen
}

schmerheim@uni-bremen.de

The recent years have seen increasing scholarly attention to the intimate entanglement of music and film, thanks to the works and edited volumes of the likes of Elisabeth Weis and John Belton (1985), Claudia Gorbman (1988), Gianluca Sergi (2004), John Kenneth Muir (2007), Jay Beck and Tony Grajeda (2008), Michel Chion (2009), Carolyn Birdsall and Anthony Enns (2011), amongst others. This should surprise no one with an awareness of the indispensable connection of both film and music with contemporary popular culture (rather, it is surprising that it took film and media studies so long to pay steadfast attention to the aural dimension of its object of inquiry).

This is the unspoken starting point of this anthology, edited by the German scholars Carsten Heinze and Laura Niebling, its twenty-two articles spread across 
482 pages. Even though only five of the articles have been written in English, international scholarship should pay attention to this predominantly Germanlanguage volume, which comprises a wonderful, voluntarily eclectic journey through the intersections between music, culture, and film. In keeping with the cultural-sociological spirit of the book series Film und Bewegtbild in Kultur und Gesel/schaft (Film and Moving Images in Culture and Society), most of the articles consider the intersections of music and film under analysis as predominantly cultural phenomena that can tell us a lot about the societies that gave rise to them.

While the bulk of the volume covers a vast range of topics, the editors' opening articles attempt to establish a common theoretical and cultural-historical perspective: Carsten Heinze, a Hamburg-based film sociologist, situates music films within the context of (largely post-WWII) youth and music cultures, while the media scholar and music journalist Laura Niebling develops a useful tentative typology of the music film, based on a distinction of modes of organization between music documentation, fictional music entertainment, and experimental music entertainment (with additional layers to those distinctions outlining four modes of representation and corresponding genres and cycles).

This sets the stage for the highly informative and readable thematic tour de force of the rest of the volume: the essays investigate casting shows as a new form of music film (written by Christian Hißnauer); explore the role of music videos in social networks (Ramón Reichert); show how Cameron Crowe's cult film Singles is also an almost involuntary documentary of the Seattle music scene shortly before it became the global Grunge revolution (Willem Strunk); take a dive into the German Schlagerfilm (Schlager music film) of the 1950s (HJ Wulff); or reflect on the astonishing case of Laibach, a Slovenian music group, part of the political art collective Neue Slowenische Kunst ("New Slovenian Art") that also inspired star philosopher Slavoj Žižek. Marcus Stiglegger discusses Laibach's controversial autorockumentary Pobeda pod Suncem ("Victory under the Sun") (1988) as an experimental political manifesto that intertwines autobiographical reflection of the band's history with an ambivalent performative reframing of fascist and socialist symbolicism (a strategy later mainstreamed by the German industrial metal band Rammstein). Another fascinating article is devoted to the unusual case of Dean Reed, a Texas-born country singer who in the 1970s and 1980s became one of the biggest stars in socialist countries in Latin America and behind the Iron Curtain, and who also starred in a number of East German Westerns which Anke Steinborn reads as apotheoses to the Hollywood-style Westerns of that period.

Since it assembles a wide range of established and up-and-coming German scholars, this edited collection is also a showcase of German-style academic film writing, which in this case combines thorough and at times sober film analysis with a solid sociological framework. However, the volume is too Euro- and Anglocentrist, since only one essay, Ivo Ritzer's Baudrillardian study of the music videos of the South African rock band The Mochines, focuses on music or film 
phenomena outside of Europe or Northern America. Additional essays on, say, Japanese or Chinese (film) music cultures would have been a welcome addition.

Another minor criticism is the underrepresentation of systematic film analysis. While almost all of the articles provide a culturally saturated discussion of the bands, films, or phenomena under investigation, there is a lack of detailed attention to the films themselves; only a few articles are really interested in the minutiae of the ways in which sound and image interact in the context of music films or videos. There certainly is ample attention to, for instance, the films' respective mise-enscène or actors, but there is little close analysis of the interplay between sound and image, of the way in which music as the dominant element influences the structure and reception of such films. There are notable exceptions. Senta Siewert's superb study of the way in which Danny Boyle's Trainspotting exploits multiple music cultures and marketing paradigms focuses on the translation of musical rhythms into visual forms, using an approach she terms "pragmatic poetics" for explaining several ways in which that process shapes not only film structure but most profoundly film reception, where the interplay of aural and visual elements can contribute towards a sensory "cutting-edge-experience" (272). Mirjam Kappes provides another predominantly analytical study with her multimodal analysis of the representation of violence in the music video L.E.S. Artistes by the singer Santigold; while Benjamin Halligan shows by way of a close reading how the promo videos of Britpop musicians such as Blur, Pulp, or The Smiths are inadvertent music documentaries that, apart from simply visually promoting an aural product, also document a group's milieu and self-perception.

To sum up: this volume assembles an impressive range of essays with a particular emphasis on the sociocultural dimension of music film. It would have been strengthened by the inclusion of at least two or three other contributions on nonWestern music film, and some of the essays would have benefitted from a stronger focus on systematic film analysis. However, this edited collection should be required reading for scholars or teachers of film and music. Hopefully at least some of the essays will at a later point also be published in English in order to make them more accessible to a non-German audience.

\section{References}

Beck, J. and Grajeda, T. Eds. 2008. Lowering the Boom: Critical Studies in Film Sound. Urbana: University of Illinois Press.

Birdsall, C. and Enns, A. Eds. 2011. Sonic Mediations: Body, Sound, Technology. Newcastle: Cambridge Scholars.

Chion, M. 2009. Film, a Sound Art. New York: Columbia University Press.

Gorbman, C. 1988. Unheard Melodies: Narrative Film Movies. London: BFI.

Muir, J. K. 2007. The Rock \& Roll Film Encyclopedia. New York: Applause Theatre \& 
Cinema Books, an imprint of Hal Leonard Corporation.

Sergi, G. 2004. The Dolby Era: Film Sound in Contemporary Hollywood. Manchester: Manchester University Press.

Weis, E. and Belton, J. Eds. 1985. Film Sound: Theory and Practice. New York: Columbia University Press. 